\title{
HUBUNGAN KANDUNGAN MINERAL KUARSA DAN MINERAL LAINNYA DENGAN SEDIMEN DASAR LAUT DI KEPULAUAN ARUAH PROVINSI RIAU
}

\author{
Oleh: \\ Deny Setiady dan Ediar Usman \\ Puslitbang Geologi Kelautan \\ Jalan DR. Junjunan No. 236, Bandung 40174
}

\section{SARI}

Secara geologi perairan Selat Malaka, termasuk dalam kawasan granit Sumatera bagian barat sebagai satu rangkaian pulau-pulau timah yang membujur dari daratan Thailand - Malaysia hingga Bangka - Belitung. Berdasarkan hal tersebut maka perairan tersebut kemungkinan kaya dengan potensi mineral-mineral letakan yang bernilai ekonomis. Tujuan penulisan paper ini adalah mengetahui hubungan kandungan mineral dengan sedimen dasar laut yang ada di daerah penelitian.

Berdasarkan analisis besar butir, sedimen yang terdapat di dasar laut daerah perairan Kepulauan Aruah adalah: pasir lanauan (zS) Pasir lempungan (cS), lanau pasiran (sZ), Lanau Lempungan (cZ), lempung lanauan ( $\mathrm{ZC}$ ) serta lempung $(\mathrm{C})$.

Berdasarkan analisis mineral, mineral di daerah penelitian terdiri dari kuarsa dengan kandungan antara $60-80 \%$. Mineral lainnya adalah zirkon, cassiterite, hematit, magnetit, limonit, biotit dan dolomit.

Endapan letakan pada sedimen permukaan dasar laut secara mekanik umumnya terkonsentrasi oleh sungai dan proses laut. Mineral kuarsa dan mineral berat adalah mineral yang merupakan endapan letakan yang berasal dari pelapukan batuan dan tertransport.

Kata kunci: Aruah, dasar laut, kuarsa, Mineral, dan sedimen.

\section{ABSTRACT}

According to the geological setting of Malaka strait, the study area is part of western Sumatera granite as tin islands series layout from Thailand terrain to Malaysian Peninsula up to Bangka Belitung Islands. Based on this condition, the study area has possibility to contain economic placer deposits. The objective of this paper is to outline the relationship between mineral content and surficial sediment in study area.

Based on grain size analysis, sediment in Aruah waters consists of silty sand, clayey sand, sandy silt, clayey silt, Silty clay and clay.

Based on mineral analysis, mineral in the study area consists of quartz with $60 \%-80 \%$ content. Other minerals are zircon, cassiterite, hematite, magnetite, limonite, biotite and dolomite.

Placer deposits in surficial sediment are mechanically concentrated by alluvial marine processes. The quartz and heavy minerals occurred in the placer deposit and derived from the transported material from rock weathering.

Keyword: Aruah, sediment, placer deposit, seabed, quartz

\section{PENDAHULUAN}

Bahan galian merupakan salah satu dari banyak jenis sumber daya alam yang berpotensi untuk meningkatkan perekonomian suatu daerah. Penyelidikan bahan galian sampai saat ini belum dilakukan secara optimal, baik terhadap kandungan mineral utamanya maupun terhadap kandungan sekundernya. Sebagai contoh endapan bahan galian pasir yang ditemukan pada saat ini belum mempunyai nilai yang ekonomis dilihat dari jumlah pasirnya, namun apabila dilihat dari 
kandungan mineralnya, kemungkinan akan menjadi sesuatu yang potensial untuk ditambang di masa yang akan datang.

Daerah penelitian merupakan daerah yang strategis karena posisinya berada pada jalur pelayaran internasional dan berbatasan dengan negara tetangga Malaysia. Salah satu aspek penting dalam pengelolaan wilayah perbatasan adalah potensi energi dan sumber daya mineral. Berdasarkan UU No. 4 tahun 2009 tentang Mineral dan Batubara atau yang dikenal dengan UU Minerba, yang telah disahkan dan diundangkan awal tahun 2009 mengamanatkan dengan jelas peluang dilakukannya penyelidikan dan atau eksplorasi umum kemineralan di wilayah perairan mulai dari 4 mil hingga 12 mil dari pantai ke arah laut. Selanjutnya, dalam rangka mewujudkan semangat UU No 43 Tahun 2008 tentang Wilayah Negara, bahwa negara juga memiliki hak-hak berdaulat di dalam dan di luar wilayah kedaulatannya dan kewenangan tertentu lainnya untuk dikelola dan dimanfaatkan sebesar-besarnya bagi kesejahteraan dan kemakmuran rakyat Indonesia. Untuk itu perlu dilakukan berbagai kajian dan inventarisasi sumber daya alam, khususnya potensi sumberdaya mineral di wilayah laut nasional dan di daerah-daerah perbatasan.

Saat ini, belum seluruh wilayah perairan nasional dan daerah perbatasan telah diketahui potensi mineral, sehingga menyulitkan dalam penetapan kebijakan pengelolaan dan pemanfaatannya. Salah satu aspek penting dalam penentuan dan pengelolaan batas di laut adalah aspek kelanjutan alamiah daratan induknya ke arah laut dan potensi sumber daya mineral hingga ke batas Negara. Daerah penyelidikan termasuk daerah penting dan berpotensi terhadap keberadaan bahan galian yang indikasi keberadaannya dapat terbentuk dari pengendapan asal daratan Sumatera, dan asal pulau-pulau granit yang banyak mengandung mineral-mineral penting.

Daerah penelitian merupakan daerah selat dimana pola arus yang berkembang dipengaruhi arus yang berasal dari darat dan arus yang berasal dari laut lepas yang masuk membentuk satu alur di sekitar perairan Kepulauan Aruah. Gelombang dan arus pasang yang datang dari laut lepas ketika mencapai perairan dangkal akan mengalami beberapa perubahan, yaitu kecepatan arus tertahan, panjang gelombang berkurang, dan energi terkumpul pada area yang lebih kecil, dan sempit serta tinggi gelombang bertambah. Pengaruh yang dapat dilihat di daerah penyelidikan berupa energi arus yang sangat kuat yang menggerus sedimen permukaan dasar laut membentuk alur-alur kedalaman dan pola sebaran endapan pasir permukaan.

Secara geografis, Kep. Aruah merupakan wilayah terluar dan secara administrasi termasuk dalam wilayah Kabupaten Rokan Hilir dan berada di ujung utara berbatasan dengan perairan Provinsi Sumatera Utara. Daerah penelitian termasuk dalam perairan Kecamatan Pasirlimau Kapas, Kabupaten Rokan Hilir Provinsi Riau dan merupakan kepulauan terluar yang berbatasan dengan perairan Malaysia.

Kepulauan Aruah meliputi beberapa gugusan pulau, antara lain: Pulau Jemur, Pulau Tukongmas, Pulau Labuan Bilik, Pulau Batuadang, Pulau Batu Berlayar, Pulau Tukong Simbang, Pulau Tukong dan Pulau Batumandi. Pulau Batuadang dan Pulau Batumandi merupakan pulau terluar yang berbatasan dengan Malaysia. (Gambar 1).

Tujuan penulisan paper ini adalah mengetahui keberadaan dan hubungan kandungan mineral kuarsa dan mineral lainnya dengan sedimen dasar laut yang ada di daerah penelitian.

Secara geologi perairan Selat Malaka, termasuk dalam kawasan granit Sumatera bagian barat sebagai satu rangkaian pulaupulau timah yang membujur dari daratan Thailand - Malaysia hingga Bangka Belitung. Jalur timah ini dikenal sebagai Tin Belt of Sumatera (Bachelor, B.C., 1983, ) (Gambar 1).

Berdasarkan kondisi geologi yang demikian, maka perairan tersebut kemungkinan kaya dengan potensi mineralmineral letakan (placer mineral) yang bernilai ekonomis. Mineral-mineral letakan tersebut berasal dari batuan granit pada pulau-pulau timah yang terdapat di perairan Selat Malaka yang telah mengalami deformasi dan pelapukan. (Cameron, N.R, 1982). Batuan beku granit di Selat Malaka dan pulau-pulau sekitarnya merupakan kesatuan batuan granit yang yang terdapat di semenanjung Malaysia yang melampar hingga ke Kalimantan Barat. Ciri-ciri batuan 
beku granit ini adalah: berwarna abu-abu kemerahan hingga kehijauan, berbutir kasar dengan komposisi feldspar, kuarsa, hornblende dan biotit. Mineral utama umumnya adalah bertekstur primer dan membentuk suatu pluton batholit yang tersingkap dengan baik di di daratan pulau-pulau di Selat Malaka. (Bachelor, B.C., 1983).

\section{Metoda Penelitian}

Metoda penelitian terdiri dari: positioning, sampling sedimen (pantai, dan dasar laut), penelitian batimetri (kedalaman laut), dan analisis besar butir serta analisis kandungan mineral.

Metoda positioning pada penelitian ini adalah untuk mengetahui posisi kapal sepanjang lintasan penelitian. Metoda ini mempergunakan peralatan Global Posotioning System (GPS) GARMIN-GPS 75 dan GARMIN-GPS 235 dengan kecepatan kapal rata-rata 4 knot/jam. Data posisi dikelola secara otomatis dan direkam pada record data, selanjutnya pemrosesan dilakukan dengan sistem komputer menggunakan program HYPACK. Beberapa peralatan yang digunakan dalam penentuan posisi kapal adalah: antenna penerima GPS; satellite navigator, Garmin GPS - 235; HYPACK, Tracking monitor, Magnavox;
(Gambar 2). Pada penelitian ini juga dipergunakan peralatan penentu posisi secara manual dengan peralatan GPS Map.

Lokasi pengambilan sampling sedimen dasar laut ditentukan berdasarkan kondisi geologi dan oseanografi di daerah penelitian. Untuk mendapatkan gambaran umum penyebaran sedimen, lokasi yang dipilih dilakukan secara grid dan sistematis, sehingga penyebaran sedimen akan benarbenar mencerminkan kondisi daerah penelitian. Pengambilan contoh sedimen dasar laut dilakukan dengan menggunakan peralatan percontoh jatuh bebas (gravity corer) dan/atau percontoh comot (grab sampler) yang disesuaikan dengan kondisi laut (Gambar 3 dan 4). Contoh sedimen permukaan dasar laut tersebut dianalisis menggunakan metoda besar butir, megaskopis dan foto mikroskopis untuk menentukan jenis sedimen dan jenis mineral.

Pengukuran kedalaman dasar laut (batimetri) dipergunakan untuk mendapatkan kedalaman permukaan dan dasar laut, serta dapat menggambarkan morfologi dasar laut berdasarkan prinsip-prinsip penjalaran gelombang. Pengukuran dilakukan secara analog, dimana data yang diperoleh direkam secara grafis dan digital.

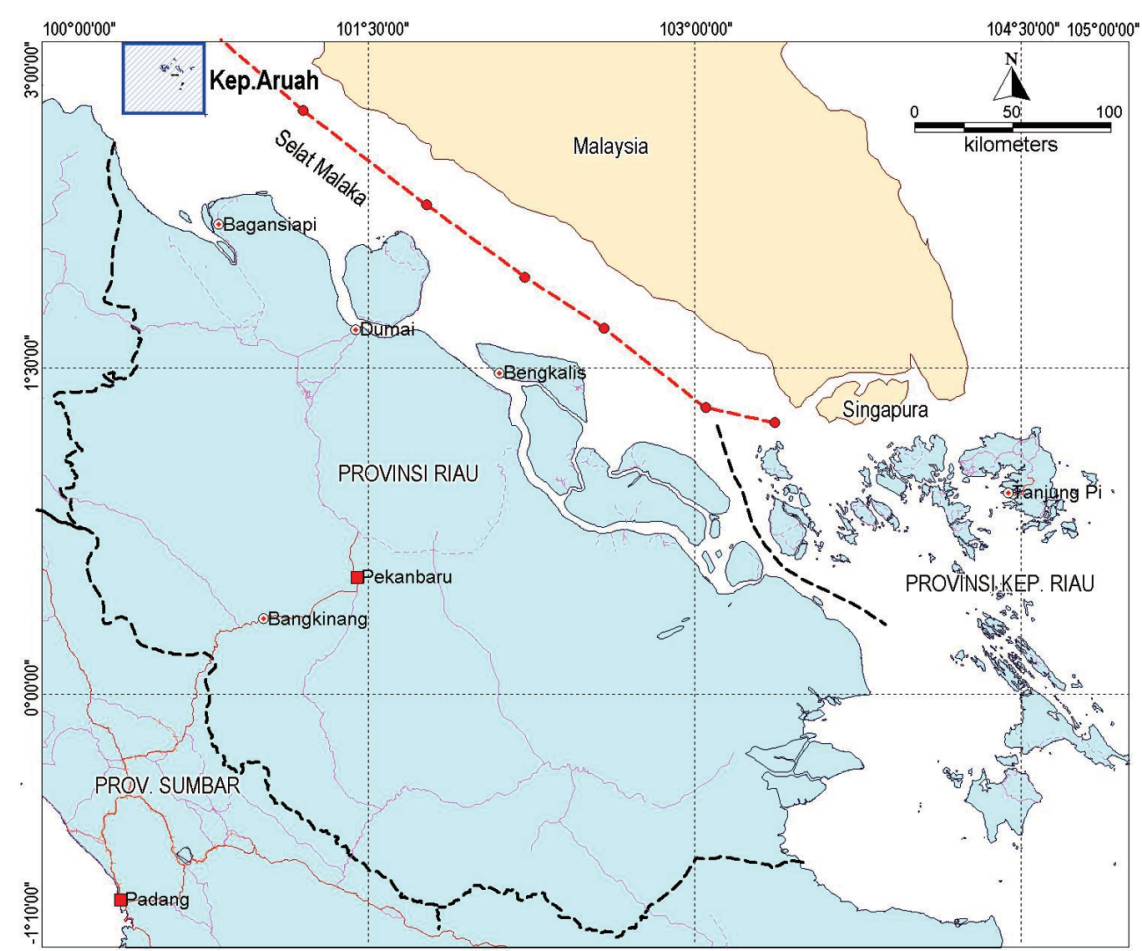

Gambar 1. Peta lokasi penelitian Kepulauan Aruah, Provinsi Riau. 


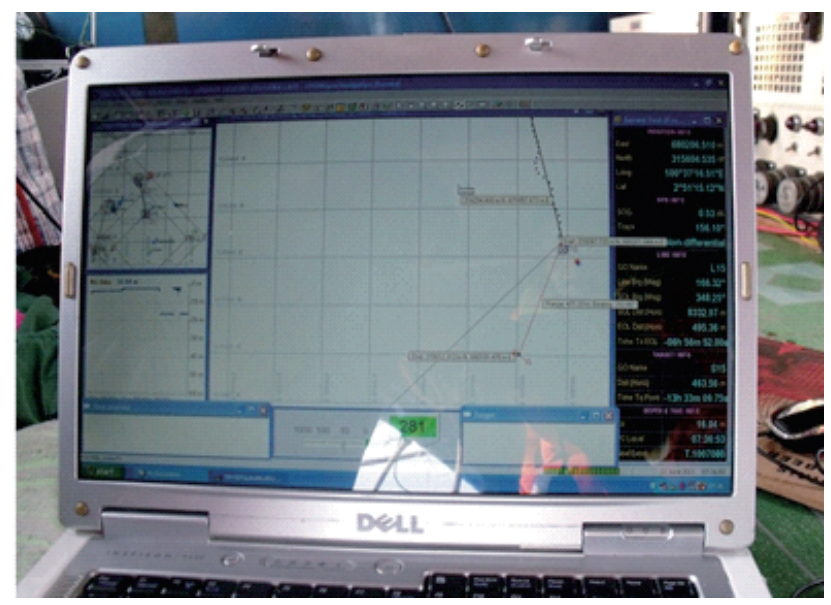

Gambar 2. Layar monitor untuk memantau posisi kapal dan lintasan penelitian di perairan Kep. Aruah.

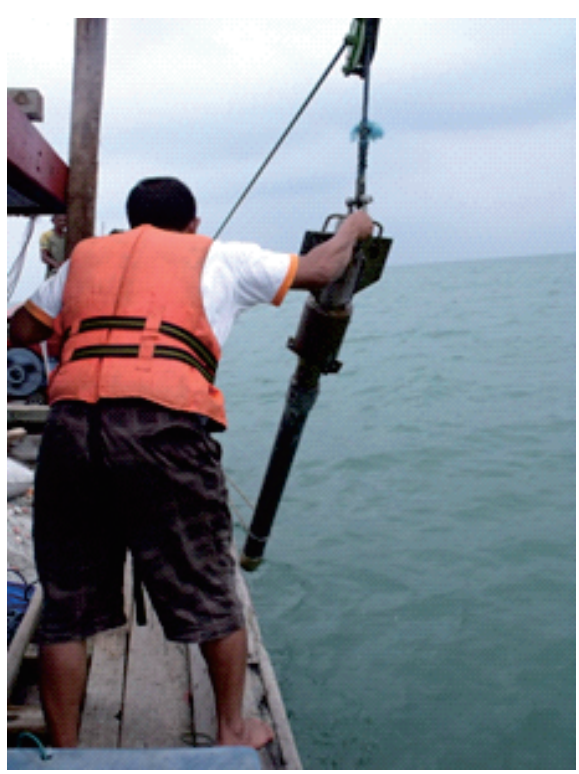

Gambar 3. Peralatan gravity corer pengambilan contoh inti sedimen di dasar laut.

Data ini diharapkan akan dapat memberikan gambaran tentang morfologi dasar laut yang bermanfaat dalam mendukung perencanaan dan pengambilan potensi sumber daya mineral. Data kedalaman yang diperoleh tersebut dikoreksi dengan data pasang surut (mean sea level) untuk mendapatkan data kedalaman terkoreksi.

Besar butir sedimen dasar laut disusun berdasarkan analisis baku dalam penelitian geologi kelautan dengan memperhatikan parameter persentase dari kandungan butiran. Data tersebut diolah secara digital dengan perangkat komputer untuk mendapatkan beberapa parameter,

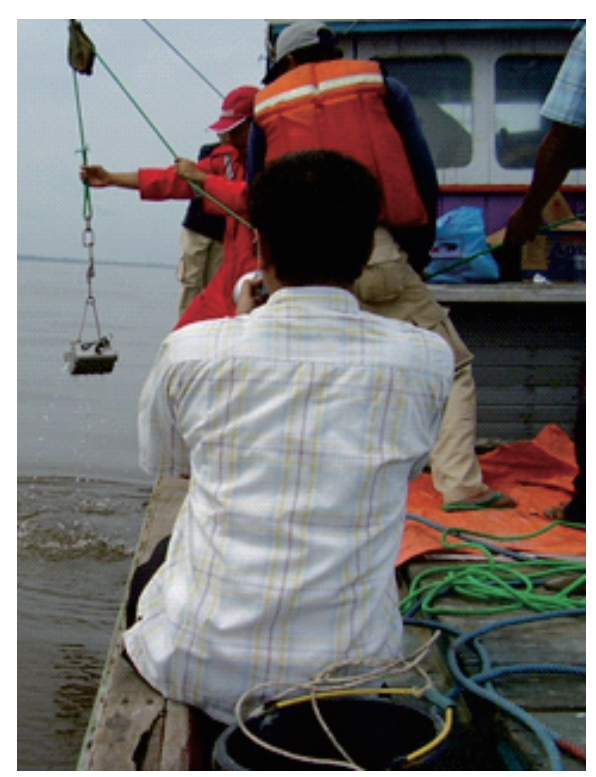

Gambar 4. Peralatan grab sampler untuk pengambilan pasir sedimen di dasar laut.

antara lain: persentase lempung (lumpur), lanau, pasir dan kerikil. Selanjutnya, pemisahan besaran lempung, lanau, pasir dan kerikil akan diperoleh klasifikasi tekstur sedimen dasar laut guna menyusun Peta Sebaran Sedimen Dasar Laut.

Analisis mineral berat dilakukan dengan menggunakan larutan berat bromoform BJ 2,88. Adapun kandungan tiap mineral berat (dalam persen) tiap lokasi diperoleh berdasarkan hasil perkalian antara perbandingan jumlah mineral yang bersangkutan terhadap jumlah keseluruhan mineral berat yang ada dengan persen total mineral berat. 


\section{MAKALAH ILMIAH}

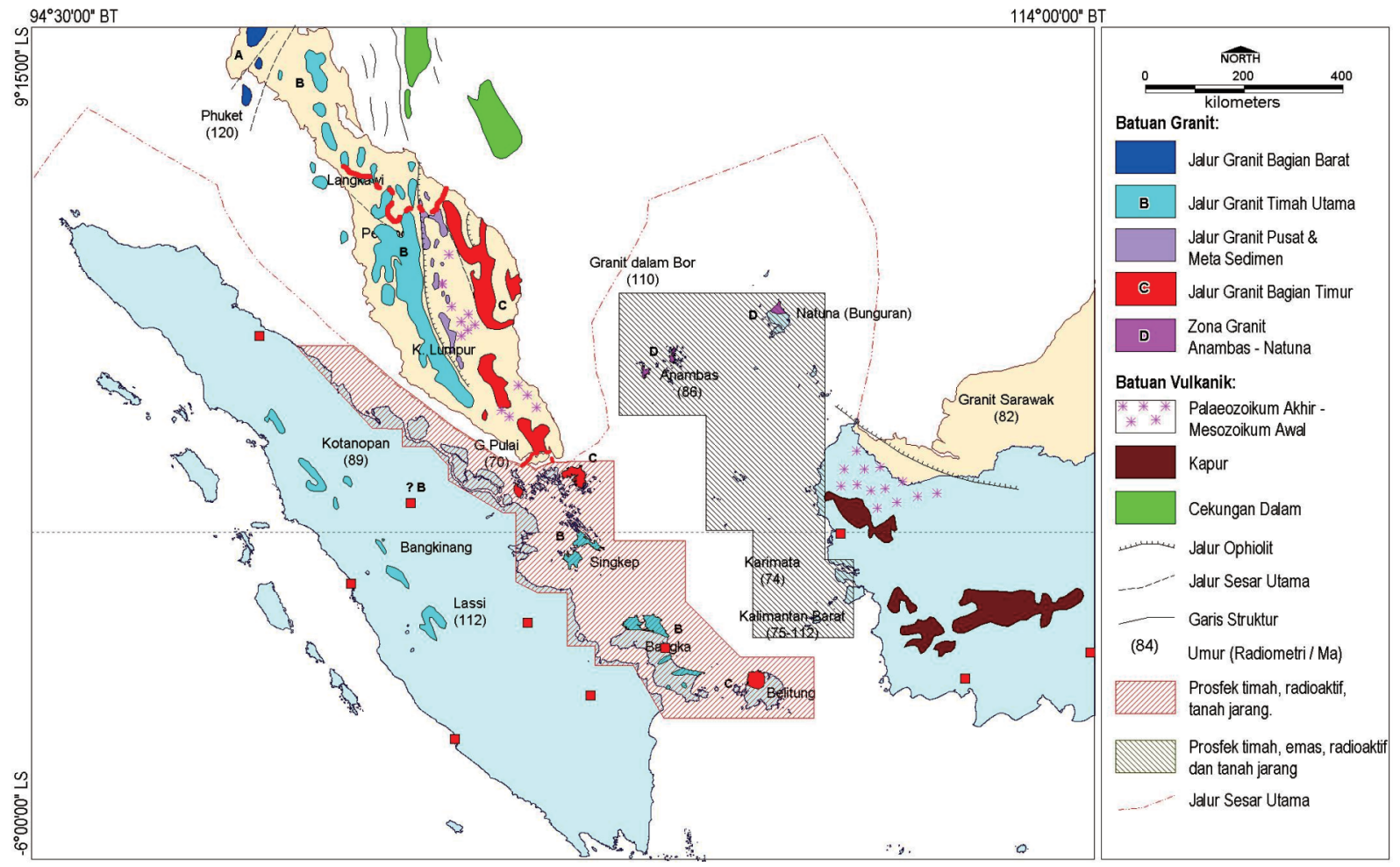

Gambar 6. Peta Geologi Perairan Selat Malaka dan selitarnya (dimodifikasi dari Batchelor, 1983; Usman dan Subandrio, 2009).

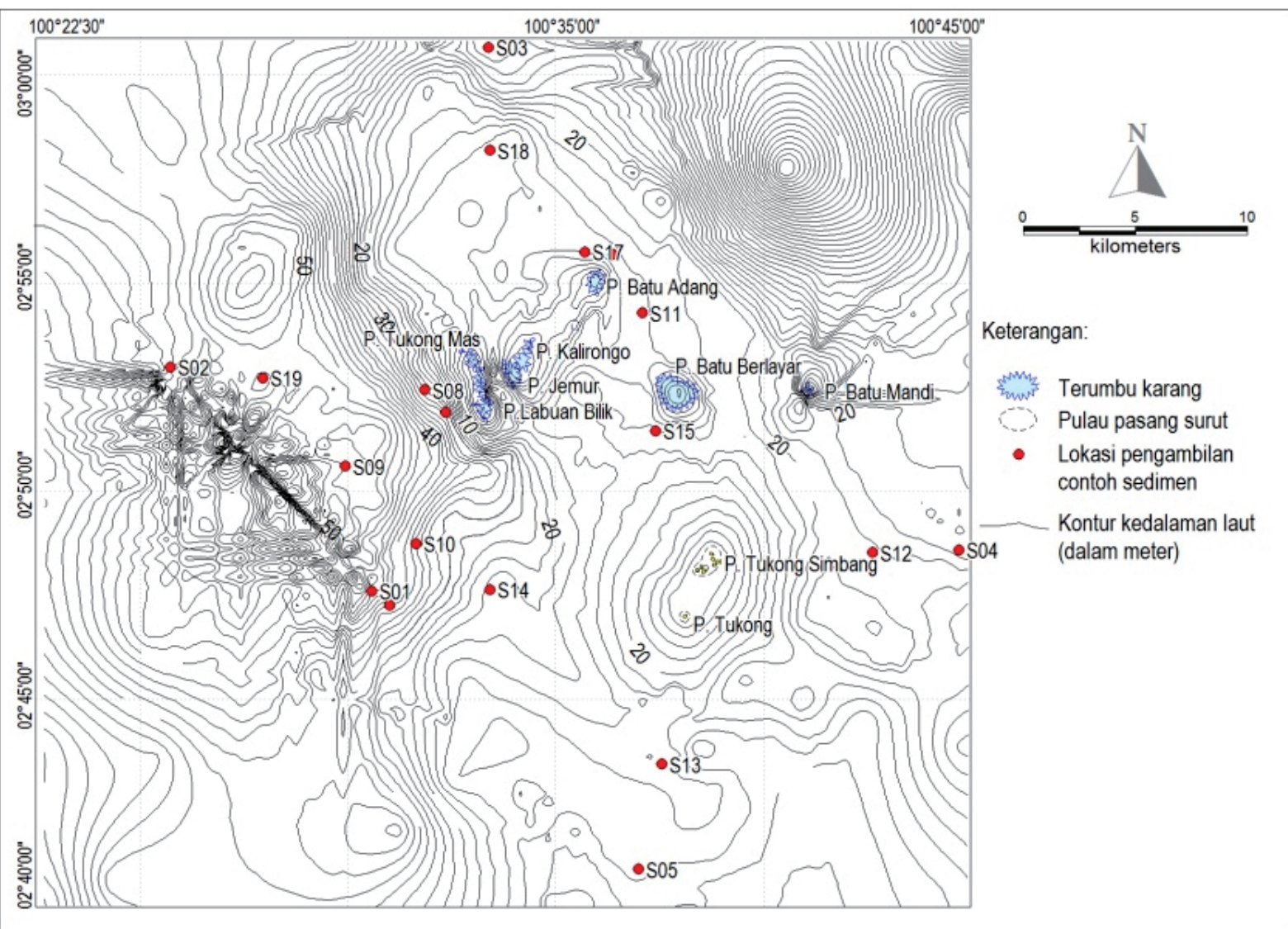

Gambar 6. Peta Batimetri Perairan Selat Malaka dan selitarnya (dimodifikasi dari Batchelor, 1983; Usman dan Subandrio, 2009). 


\section{HASIL PENELETIAN}

\section{Kedalaman Dasar Laut}

Berdasarkan hasil pengukuran kedalaman dasar laut di perairan Kepulauan Aruah dan sekitarnya menunjukkan kedalaman minimum terdapat di sekitar garis pantai dan terdalam terdapat di sekitar daerah bagian barat Pulau Labuan Bilik dan utara Pulau Batu Mandi (Gambar 7). karena morfologi nya yang curam

\section{Morfologi Paparan}

Morfologi paparan merupakan morfologi dengan permukaan yang landai dan hampir datar. Morfologi ini berkembang di sekitar Pulau Labuan Bilik dan Pulau Jemur. morfologi paparan berkembang sebagai hasil proses transportasi sedimen dari arah puncak pulau-pulau kecil ke arah

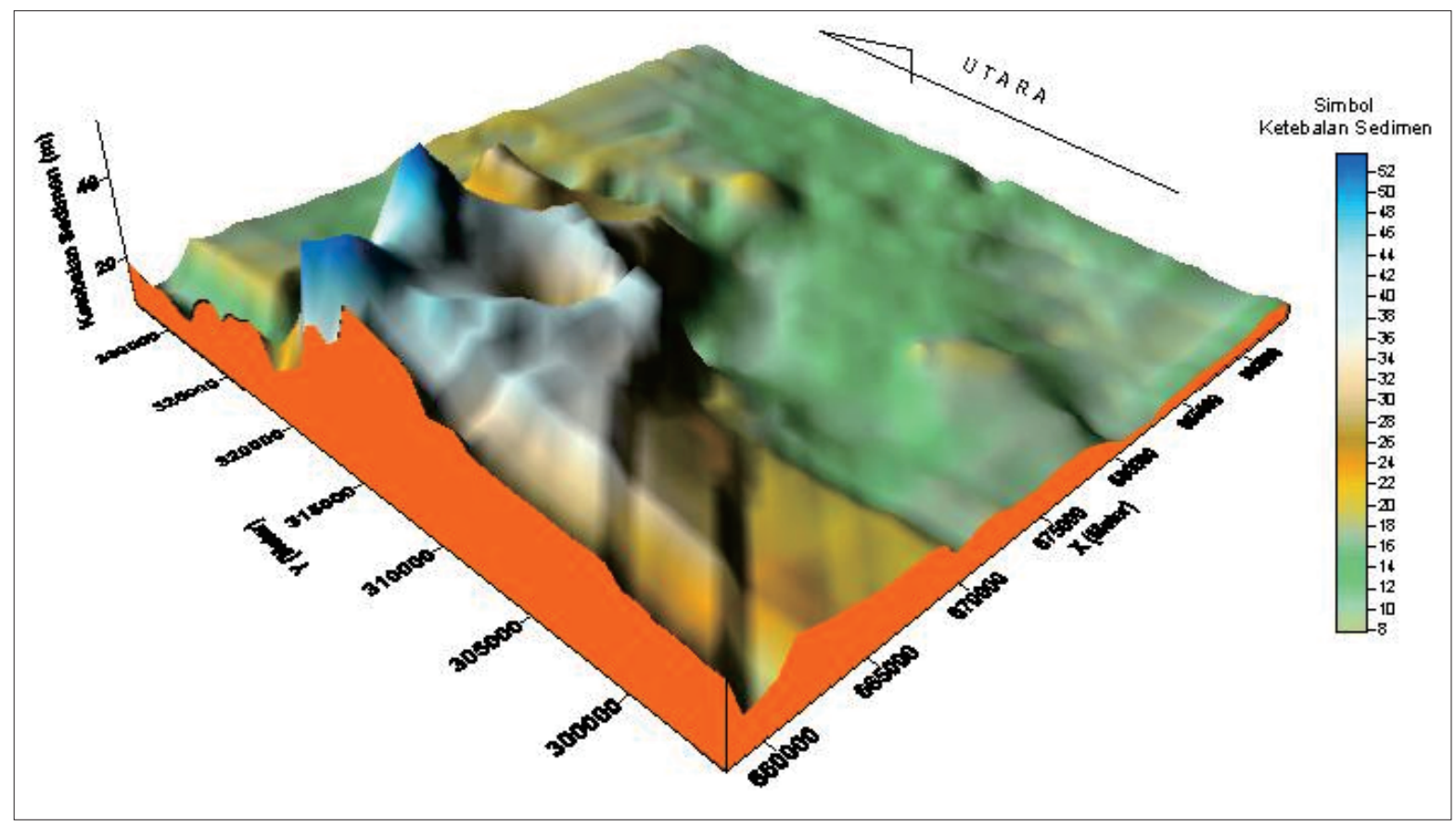

Gambar 7. Blok Diagram Kedalaman dasar laut dalam penentuan morfologibdasar laut Perairan Selat Malaka dan selitarnya

Sedangkan berdasarkan blok diagram 3D (gambar-4), secara umum, morfologi di perairan Kepulauan Aruah dapat dibagi menjadi tiga bagian, yaitu: morfologi lembah bergelombang, morfologi paparan dan morfologi kawasan pantai.

\section{Morfologi Lembah Bergelombang}

Morfologi lembah bergelombang ini berkembang di bagian barat Pulau Labuan Bilik ke arah selatan dan timur. Lembah terdalam terdapat di utara Pulau Batu Mandi dan bagian barat Pulau Labuan Bilik. Bagian yang lain umumnya bergelombang dengan kedalaman berkisar antara 10 - 50 meter, dan lembah terdalam membentuk pola bulatmemanjang dengan kedalaman antara 50 80 meter di bawah permukaan laut. Pada daerah ini sedimen jarang terendapkan laut mengisi lembah-lembah di sekitar gugusan pulau-pulau kecil. Kedalaman paparan berkisar antara 10 - 30 meter di bawah permukaan laut.

\section{Morfologi Kawasan Pantai}

Morfologi Kawasan Pantai merupakan morfologi dataran pantai yang mengitari pantai hingga kedalaman laut kurang dari 5 meter. Morfologi ini pada saat air laut surut membentuk kawasan yang luas. Morfologi kawasan pantai dibentuk oleh proses interaksi antara proses geologi (erosi, sedimentasi dan transportasi) dan proses laut (pengendapan).

Secara umum kedalaman dasar laut di daerah penelitian berkisar antara 5 - 55 meter; dimana dari 0 meter di sekitar pulau dan semakin dalam ke arah lepas pantai. 


\section{MAKALAH ILMIAH}

Secara regional kedalaman dasar laut dari selatan ke utara semakin dalam, dimana bagian terdalam terdapat di bagian utara $P$. Batu Adang ke arah bagian tengah Selat Malaka.

\section{Pengambilan Contoh Sedimen Dasar Laut}

Jumlah contoh sedimen permukaan dasar laut sebanyak 19 contoh (gambar 8), terdiri dari pengambilan contoh menggunakan peralatan gravity corer (GC) berjumlah 8 contoh, grab sampler (GS) berjumlah 11 contoh dan 3 contoh pantai. Berdasarkan analisis besar butir sedimen permukaan dasar laut dan sedimen pantai di perairan Kepulauan Aruah diperoleh jenis dan satuan sedimen permukaan dasar laut dan pantai sebagai berikut: yaitu pasir lanauan, pasir lempungan, lempung, lempung lanauan, lanau pasiran, dan lanau lempungan. Secara detail terdapat pada Tabel 2.

Berdasarkan analisis besar butir, kemudian dimasukkan ke dalam tabel ukuran butir (skala Wentworth, 1922) dan penamaan sedimen berdasarkan Folk (1980), umumnya ukuran butir bervariasi mulai lempung (ukuran $0,0039 \mathrm{~mm}$ ) sampai pasir kasar (ukuran 1,41 mm). Ukuran terkecil di daerah penelitian adalah lempung sampai lempung lanauan dan ukuran butir terbesar adalah pasir. Berdasarkan hasil pengamatan tersebut, dapat dikelompokkan menjadi beberapa satuan, yaitu: lempung (C), lanau lempungan (cZ), lanau pasiran (sZ), pasir lempungan (cS), lempung lanauan $(\mathrm{zC})$ dan pasir lanauan ( $\mathrm{zS}$ ). dan dibuat peta sebaran sedimen (gambar 9). Sedangkan berdasarkan analisis besar butir di daerah pantai umumnya adalah sedimen pasir.

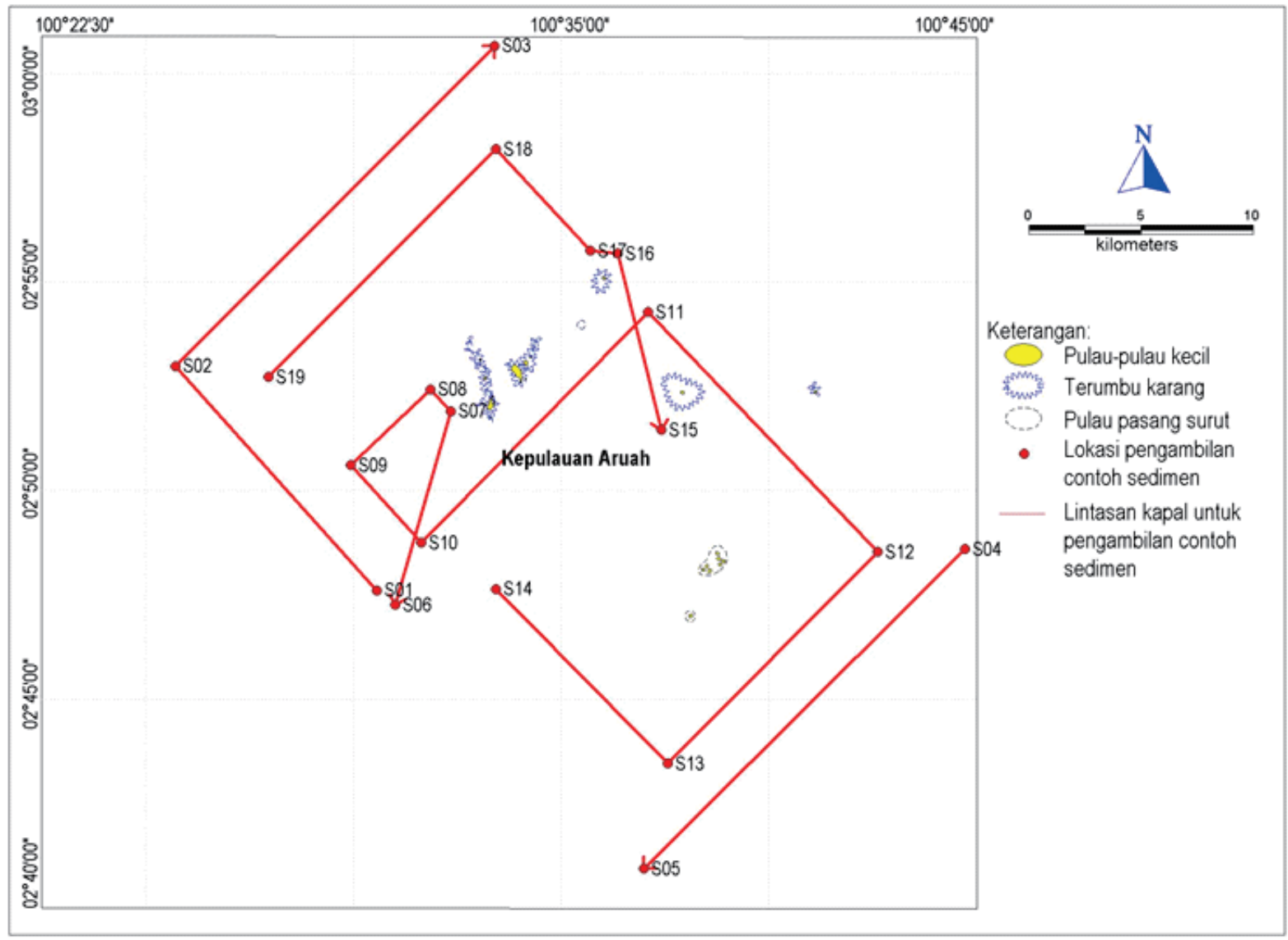

Gambar 8. lintasan kapal dan lokasi pengambilan contoh sedimen dasar laut di Kepulauan Aruah. 
Tabel 1.

Hasil pengambilan contoh sedimen dan analisis besar butir sedimen.

\begin{tabular}{|c|c|c|c|c|c|c|c|}
\hline No. & $\begin{array}{l}\text { Kode } \\
\text { Contoh }\end{array}$ & Alat & $\begin{array}{l}\text { Kedalaman } \\
\text { Laut }(\mathrm{m})\end{array}$ & $\begin{array}{c}\text { Panjang } \\
\text { Contoh } \\
\text { (Cm) }\end{array}$ & \multicolumn{2}{|c|}{ Koordinat } & Keterangan \\
\hline S1. & KA-01 & GS & 49,9 & - & $100,510^{\circ} \mathrm{E}$ & $2,79347^{\circ} \mathrm{N}$ & Pasir lanauan \\
\hline S2. & KA-02 & GS & 50,6 & - & $100,429^{\circ} \mathrm{E}$ & $2,88310^{\circ} \mathrm{N}$ & $\begin{array}{l}\text { Pasir } \\
\text { lempungan }\end{array}$ \\
\hline S3. & KA-03 & GS & 34,3 & - & $100,556^{\circ} \mathrm{E}$ & $3,01107^{\circ} \mathrm{N}$ & $\begin{array}{l}\text { Lempung } \\
\text { lanauan }\end{array}$ \\
\hline S4. & KA-04 & GS & 25,2 & - & $100,745^{\circ} \mathrm{E}$ & $2,81001^{\circ} \mathrm{N}$ & Lanau pasiran \\
\hline S5. & KA-05 & GS & 13,5 & - & $100,616^{\circ} \mathrm{E}$ & $2,68222^{\circ} \mathrm{N}$ & $\begin{array}{l}\text { Lanau } \\
\text { lempungan }\end{array}$ \\
\hline S6. & KA-06 & $\mathrm{GC}$ & 42,6 & 90 & $100,517^{\circ} \mathrm{E}$ & $2,78772^{\circ} \mathrm{N}$ & Lanau pasiran \\
\hline S7. & KA-07 & GC & 31,4 & 76 & $100,539^{\circ} \mathrm{E}$ & $2,86505^{\circ} \mathrm{N}$ & $\begin{array}{l}\text { Lanau } \\
\text { lempungan }\end{array}$ \\
\hline S8. & KA-08 & $\mathrm{GC}$ & 27,7 & 113 & $100,531^{\circ} \mathrm{E}$ & $2,87380^{\circ} \mathrm{N}$ & Lempung \\
\hline S9. & KA-09 & GC & 54,9 & 43 & $100,499^{\circ} \mathrm{E}$ & $2,84344^{\circ} \mathrm{N}$ & Pasir lanauan \\
\hline S10. & KA-10 & GC & 33,5 & 74 & $100,527^{\circ} \mathrm{E}$ & $2,81246^{\circ} \mathrm{N}$ & Pasir lanauan \\
\hline S11. & KA-11 & GC & 13,9 & 109 & $100,618^{\circ} \mathrm{E}$ & $2,90468^{\circ} \mathrm{N}$ & Lanau pasiran \\
\hline $\mathrm{S} 12$ & KA-12 & GC & 22,1 & 76 & $100,710^{\circ} \mathrm{E}$ & $2,80883^{\circ} \mathrm{N}$ & $\begin{array}{l}\text { Pasir } \\
\text { lempungan }\end{array}$ \\
\hline S13. & KA-13 & GC & 16,5 & 98 & $100,626^{\circ} \mathrm{E}$ & $2,72419^{\circ} \mathrm{N}$ & $\begin{array}{l}\text { Lempung } \\
\text { lanauan }\end{array}$ \\
\hline S14. & KA-14 & GS & 19,2 & - & $100,557^{\circ} \mathrm{E}$ & $2,79406^{\circ} \mathrm{N}$ & $\begin{array}{l}\text { Pasir } \\
\text { lempungan }\end{array}$ \\
\hline S15. & $\mathrm{KA}-15$ & GS & 14,5 & - & $100,623^{\circ} \mathrm{E}$ & $2,85759^{\circ} \mathrm{N}$ & Pasir lanauan \\
\hline S16. & KA-16 & GS & 12,9 & - & $100,606^{\circ} \mathrm{E}$ & $2,92807^{\circ} \mathrm{N}$ & $\begin{array}{l}\text { Lempung } \\
\text { lanauan }\end{array}$ \\
\hline S17. & KA-17 & GS & 13,4 & - & $100,595^{\circ} \mathrm{E}$ & $2,92916^{\circ} \mathrm{N}$ & $\begin{array}{l}\text { Lempung } \\
\text { lanauan }\end{array}$ \\
\hline S18. & KA-18 & GS & 11,4 & - & $100,557^{\circ} \mathrm{E}$ & $2,96972^{\circ} \mathrm{N}$ & $\begin{array}{l}\text { Lempung } \\
\text { lanauan }\end{array}$ \\
\hline S19. & KA-19 & GS & 51,6 & - & $100,466^{\circ} \mathrm{E}$ & $2,87865^{\circ} \mathrm{N}$ & $\begin{array}{l}\text { Pasir } \\
\text { lempungan }\end{array}$ \\
\hline $\mathrm{S} 20$ & KA-20 & - & $\begin{array}{l}\text { P.Sarong } \\
\text { Alang }\end{array}$ & - & $100.555^{\circ} \mathrm{E}$ & $2.86822^{\circ} \mathrm{N}$ & $\begin{array}{l}\text { Pasir } \\
\text { (Pantai) }\end{array}$ \\
\hline
\end{tabular}

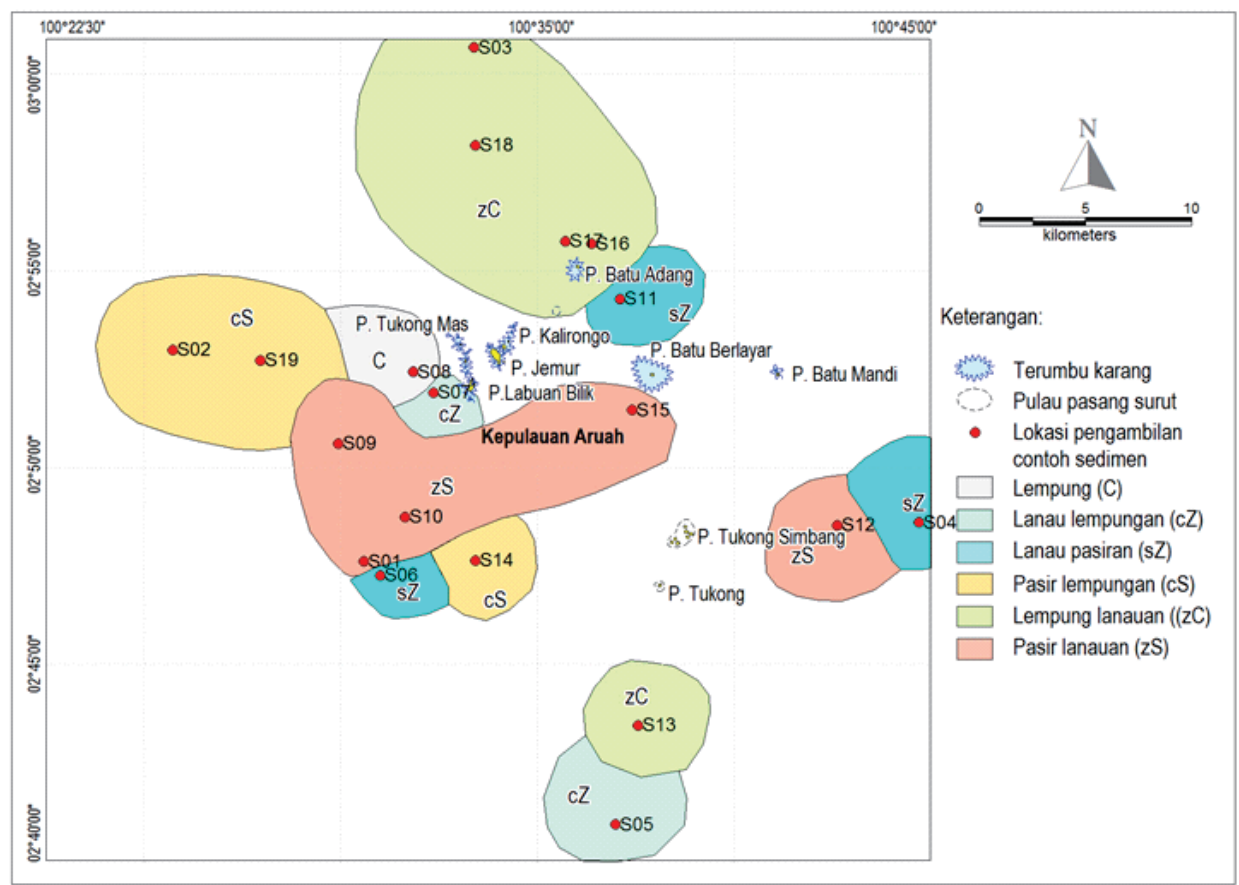

Gambar 9. Peta penyebaran sedimen permukaan dasar laut di perairan Kepulauan Aruah, Provinsi Riau 


\section{Sumber Daya Mineral}

Contoh sedimen yang dianalisis adalah contoh yang mengandung komposisi ukuran pasir lempungan sampai pasir, dilakukan dengan menggunakan mikroskop untuk persentase kandungan butiran mineral. Berdasarkan analisis mineral yang dilakukan di laboratorium terhadap 11 sampling sedimen permukaan dasar laut untuk dianalisa mineral beratnya, didapatkan delapan jenis mineral yang terdiri dari kuarsa, Magnetit, Kasiterit, Zirkon, hematite, limonit, biotit dan dolomite. (Tabel2), mineral tersebut secara deskripsi terdiri dari:

Kuarsa $\left(\mathrm{SiO}_{2}\right)$ di dapatkan diseluruh contoh yang dianalisa. Kuarsa adalah mineral yang sangat umum terdapat pada kerak bumi dan merupakan mineral yang sangat penting dalam pembentukan batuan beku. Di beberapa tempat terdapat pasir yang mengandung kuarsa antara $60-80 \%$. Kuarsa, umumnya bening, tetapi kadangkadang putih kekuningan. Beberapa kuarsa digunakan sebagai batu perhiasan, pembuat gelas (Herbert S. Zim, 1978).

Magnetit $\left(\mathrm{Fe}_{3} \mathrm{O}_{4}\right)$, termasuk group oksida, Hitam agak kebiruan, membulat, kilap submetalik, sepintas mirip ilmenit , tetapi agak buram, magnetit terbentuk dibawah kondisi yang agak lemah dibanding hematit dan terjadi berupa endapan bijih. terjadi pada beberapa tipe batuan magmatik, pegmatit, kontak metasomatik berat jenis 5.2. Magnetit digunakan sebagai campuran pada besi, dan baja Di daerah penyelidikan magnetit terdapat pada seluruh contoh sedimen permukaan dasar laut dengan kandungan terbesar pada S-12 B sebesar $5 \%$.

Kasiterit $\left(\mathrm{SnO}_{2}\right)$,termasuk group oksida, merah kecoklatan, prismatik, identik dengan rutil, kekerasan $6-7$, berat jenis 6,8 7,0. sinonim dengan bijih timah, endapan Kasiterit genesanya berasosiasi dengan batu beku asam terutama granit. terbentuk pada akumulasi pegmatit, endapan kontak metasomatik dan hydrothermal. Kasiterit digunakan untuk solder, untuk keramik, timah pada campuran tembaga. Didaerah selidikan kasiterit terdapat pada seluruh contoh sedimen permukaan dasar laut dengan kandungan $1-2 \%$.
Hematit $\left(\mathrm{Fe}_{2} \mathrm{O}_{3}\right)$, termasuk group oksida, hitam kecoklatan, bentuk membulat, kilap submetalik kekerasan $5,5-6$, berat jenis 5 - 5,2. Hematite ditemukan seluruh contoh yang dianalisis dengan kandungan antara $1-5 \%$.

Zirkon $\left(\mathrm{ZrSiO}_{4}\right)$, termasuk group silikat Putih/bening, prismatik, permukaan datar kekerasan $7-8$, berat jenis 4,68-4,7. merupakan unsur radioaktiv, terjadi pada daerah yang kecil pada batuan intrusi magmatik, nephelin, syenit, granit, diorit. Zirkon karena bentuknya yang bagus digunakan untuk batu perhiasan, di daerah penelitian zircon hanya ada di 5 lokasi penelitian dengan kandungan $1 \%$.

Biotit $\mathrm{KAl}_{2}\left(\mathrm{Si}_{3} \mathrm{Al}\right) \mathrm{O}_{10}(\mathrm{OH}, \mathrm{F})$, termasuk group silikat (Mika), bentuk berlembar tipistipis, kilap mutiara, kekerasan 2 - 35, berat jenis 2,76 - 3,10, umumnya terjadi pada batuan beku intusi granit. Biotit ditemukan pada seluruh lokasi contoh sedimen dasar lautlaut dan 2 lokasi pantai, dengan kandungan antara $1 \%-4 \%$

Dolomit ditemukan pada seluruh lokasi contoh sedimen dasar lautlaut dan dua lokasi pantai, dengan kandungan antara $1 \%-3 \%$ mineral dolomit, sedangkan cangkang kerang ditemukan di semua lokasi contoh laut yang dianalisa dan dua contoh pantai hal ini menunjukkan bahwa lingkungan pengendapan daerah selidikan dipengaruhi oleh kondisi marin (laut), (Herbert S. Zim, 1978).

Secara umum pada semua contoh yang dianalisis mineral yang umum dijumpai adalah kuarsa dengan komposisi antara 60 $80 \%$. Mineral lainnya adalah zirkon, timah, hematit, magnetit, limonit, biotit dan dolomit (Tabel 2). Pada contoh sedimen di laut tidak seluruhnya merupakan butiran mineral, terdapat mineral lempung dan cangkang. Mineral lempung dan cangkang dipisahkan dari contoh pasir.

Kandungan mineral pada sedimen pasir ditemukan pada contoh sedimen pantai di Pulau Jemur, Pulau Sarong Alang dan Pulau Labuan Bilik, dengan kandungan mineral kuarsa antara $70 \%-80 \%$, kasiterit $1 \%$, hematit $2 \%-3 \%$, magnetit, Biotet $1 \%$ $3 \%$, dolomit $15-2 \%$. 
Tabel 2.

Hasil analisis sumber daya mineral di perairan Kepulauan Aruah.

\begin{tabular}{|c|c|c|c|c|c|c|c|c|c|c|c|c|c|}
\hline \multirow{2}{*}{ No } & \multirow{2}{*}{$\begin{array}{c}\text { No } \\
\text { Sampling }\end{array}$} & \multirow{2}{*}{ Metoda } & \multirow{2}{*}{$\begin{array}{c}\text { Jenis } \\
\text { Sedimen }\end{array}$} & \multirow{2}{*}{ Cangkang } & \multicolumn{9}{|c|}{ Persentase Mineral (\%) } \\
\hline & & & & & Kuarsa & Zircon & Kasiterit & Hematit & Magnetit & Limonit & Biotit & Dolomit & Kumulatif \\
\hline 1 & KA 01 & $\begin{array}{c}\text { Grab } \\
\text { sampler }\end{array}$ & $\begin{array}{c}\text { Pasir } \\
\text { lanauan }\end{array}$ & 10 & 80 & 1 & 1 & 1 & 2 & - & 2 & 3 & 100 \\
\hline 2 & KA 02 & $\begin{array}{c}\text { Grab } \\
\text { sampler }\end{array}$ & $\begin{array}{c}\text { Pasir } \\
\text { lempungan }\end{array}$ & 15 & 75 & - & 1 & 2 & 3 & - & 2 & 2 & 100 \\
\hline \multirow{2}{*}{3} & \multirow{2}{*}{ KA 09} & \multirow{2}{*}{$\begin{array}{c}\text { Gravity } \\
\text { corer }\end{array}$} & \multirow{2}{*}{$\begin{array}{c}\text { Pasir } \\
\text { lempungan }\end{array}$} & 15 & 70 & - & 2 & 5 & 4 & - & 2 & 2 & 100 \\
\hline & & & & 20 & 65 & - & - & 4 & 3 & 1 & 4 & 3 & 100 \\
\hline \multirow{2}{*}{4} & \multirow{2}{*}{ KA 10} & \multirow{2}{*}{$\begin{array}{c}\text { Gravity } \\
\text { corer }\end{array}$} & \multirow{2}{*}{$\begin{array}{c}\text { Pasir } \\
\text { Ianauan }\end{array}$} & 20 & 70 & - & 1 & 3 & 2 & - & 2 & 2 & 100 \\
\hline & & & & 10 & 85 & - & - & 1 & 2 & - & 1 & 1 & 100 \\
\hline \multirow{2}{*}{5} & \multirow{2}{*}{ KA 12} & \multirow{2}{*}{$\begin{array}{l}\text { Gravity } \\
\text { corer }\end{array}$} & \multirow{2}{*}{$\begin{array}{c}\text { Pasir } \\
\text { lempungan }\end{array}$} & 10 & 80 & - & 1 & 3 & 2 & - & 1 & 3 & 100 \\
\hline & & & & 10 & 75 & - & - & 5 & 5 & - & 3 & 2 & 100 \\
\hline 6 & KA 14 & $\begin{array}{c}\text { Grab } \\
\text { sampler }\end{array}$ & $\begin{array}{c}\text { Pasir } \\
\text { lempungan }\end{array}$ & 20 & 70 & 1 & - & 2 & 1 & - & 3 & 3 & 100 \\
\hline 7 & KA 15 & $\begin{array}{c}\text { Grab } \\
\text { sampler }\end{array}$ & $\begin{array}{c}\text { Pasir } \\
\text { lanauan }\end{array}$ & 20 & 65 & 1 & 2 & 5 & 3 & - & 2 & 2 & 100 \\
\hline 8 & KA 19 & $\begin{array}{c}\text { Grab } \\
\text { sampler }\end{array}$ & $\begin{array}{c}\text { Pasir } \\
\text { lanauan }\end{array}$ & 30 & 60 & 1 & 1 & 3 & 2 & - & 1 & 2 & 100 \\
\hline 9 & \multicolumn{2}{|c|}{ P. Jemur } & Pasir & 17 & 70 & 1 & 2 & 2 & 5 & - & 1 & 2 & 100 \\
\hline 10 & \multicolumn{2}{|c|}{ P. Sarong Alang } & Pasir & 10 & 80 & - & 1 & 2 & 3 & - & 3 & 1 & 100 \\
\hline 11 & \multicolumn{2}{|c|}{ P. Labuan Bilik } & Pasir & 17 & 75 & - & 1 & 3 & 1 & - & 1 & 2 & 100 \\
\hline
\end{tabular}

\section{PEMBAHASAN}

Secara umum, seluruh contoh yang dianalisis menunjukkan kehadiran butiran lanau dan pasir, sedikit lempung dan pada beberapa contoh ditemukan cangkang dalam kondisi yang masih utuh. Butiran yang umum terbentuk dari butiran kuarsa dan mineral berat berwarna kehitaman. Kandungan kuarsa berasal dari rombakan batuan sedimen Tersier yang terdapat di bagian darat pulau-pulau kecil. Adanya butiran pasir menunjukkan pola arus dan gelombang yang kuat, sehingga butiran berukuran pasir dapat tertransport ke arah lepas pantai, sedangkan butiran halus (lempung) mengendap di daerah lembah di bagian barat dan utara Pulau Jemur.

Kandungan mineral kuarsa yang terdapat di daerah penelitian dominan terdapat pada sedimen pasir lanauan dan pasir lempungan dengan kedalaman dasar laut antara 11 meter sampai 55 meter, dimana sedimen tersebut agak ketengah jauh dari pulau, sedangkan di sekeliling pulau berupa terumbu karang sehingga agak menyulitkan unruk mengambil contoh sedimen dasar laut.

Berdasarkan gambar 10 grafik persentase mineral kuarsa hasil sedimen grab (di permukaan dasar laut) terlihat bahwa kandungan mineral kuarsa antara $60 \%-80 \%$, sedangkan dari hasil sedimen gravity core (GC) yaitu S9, S10,dan S12, dilakukan dua analisis di bagian bawah dan bagian atas. Ternyata kandungan mineral kuarsa di temukaan di permukaan dan di bagian bawah sampel, hal ini menunjukkan bahwa mineral kuarsa sangat melimpah di daerah penelitian.

Berdasarkan gambar 11 grafik presentasi kandungan mineral magnetit, hematit, biotit dan dolomit terlihat bahwa mineral - mineral tersebut terdapat di semua lokasi yang di analisisi tetapi sangat sedikit kandungannya dibandingkan kuarsa, dan menjukkan arah kandungan yang hampir sama. Di setiap lokasi kandungan magnetit lebih banyak disusul mineral hematit, kemudian dolomit dan mineral biotit paling sedikit.

Gambar 12 adalah peta penyebaran sedimen dasar laut yang dikombinasikan dengan peta kontur kedalaman dasar laut. Sedimen pasir lempungan dan pasir lanauan yang mengandung mineral ekonomis terdapat pada kedalaman $20-50$ meter. Hal ini akan sangat potensial untuk ditambang karena tidak terlalu dalam.

Adanya butiran pasir menunjukkan pola arus dan gelombang yang kuat, sehingga butiran berukuran pasir dapat tertransport ke arah lepas pantai, sedangkan butiran halus (lempung) mengendap di daerah lembah di bagian barat dan utara P. Jemur.

Umumnya butiran mineral masih menunjukkan sudut membentuk butiran menyudut tanggung (sub-angular). Butiran menyudut tanggung menunjukkan kondisi yang tidak jauh dari sumbernya. Kondisi ini juga memperkuat dugaan bahwa butiran kuarsa tidak berasal secara langsung dari batuan granit. Di daerah pantai, hampir seluruh sedimen di pantai membentuk hamparan pasir putih. Hasil pengamatan 


\section{MAKALAH ILMIAH}

pada mikroskop, butiran terbesar adalah kuarsa dan mineral berat lainnya. Adanya butiran kuarsa berasal dari rombakan satuan batupasir pada sedimen Tersier yang menyusun pulau-pulau kecil di Kepulauan
Aruah. Hal ini ditunjukkan dari hasil analisis mineral ternyata kandungan mineral pada sedimen di dasar laut hampir sama dengan kandungan mineral pada sedimen pantai

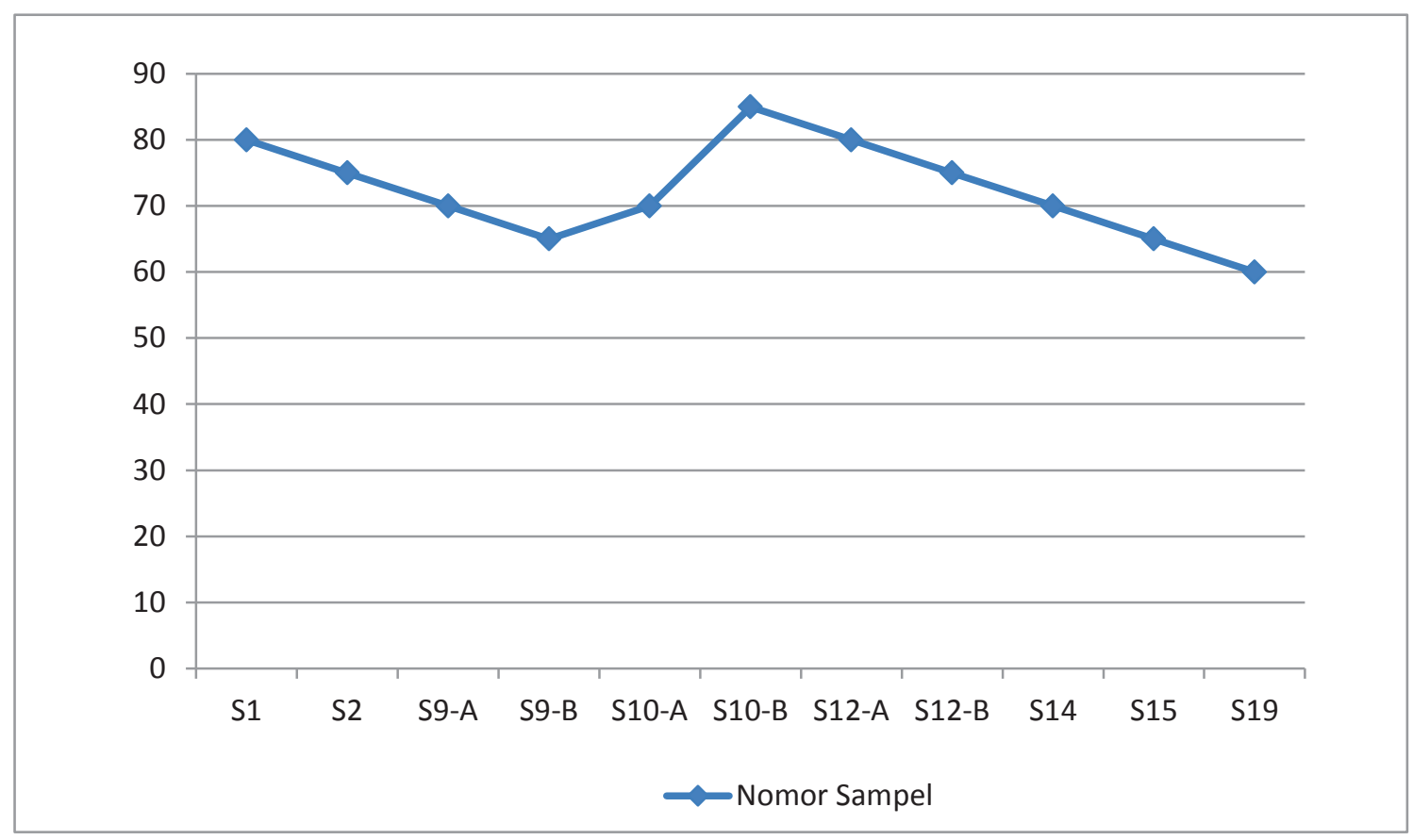

Gambar 10. Grafik Persentasi Kandungan mineral Kuarsa

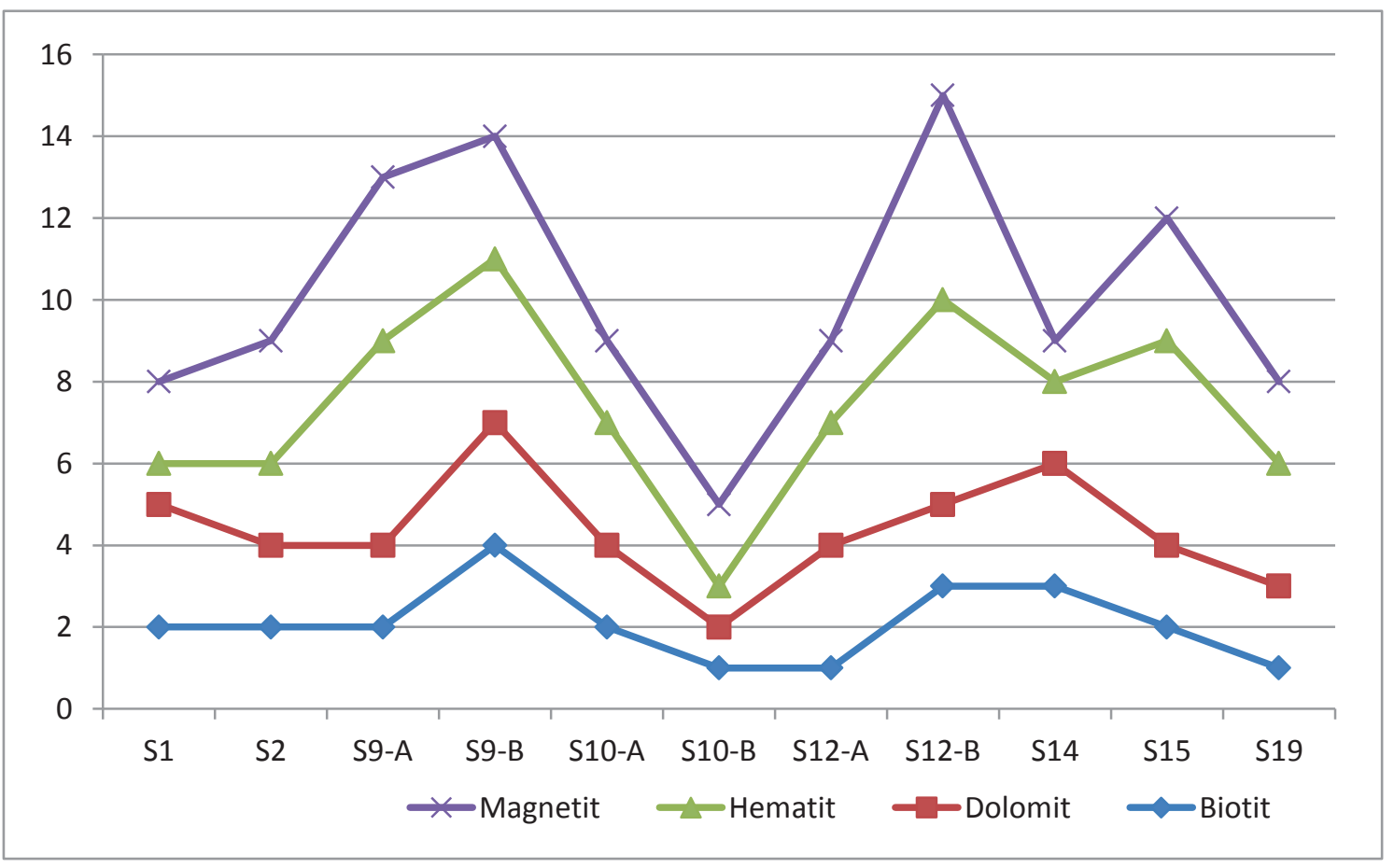

Gambar 11. Grafik Persentasi Kandungan mineral Hematit, magnetit, dolomite dan biotit 


\section{MAKALAH ILMIAH}

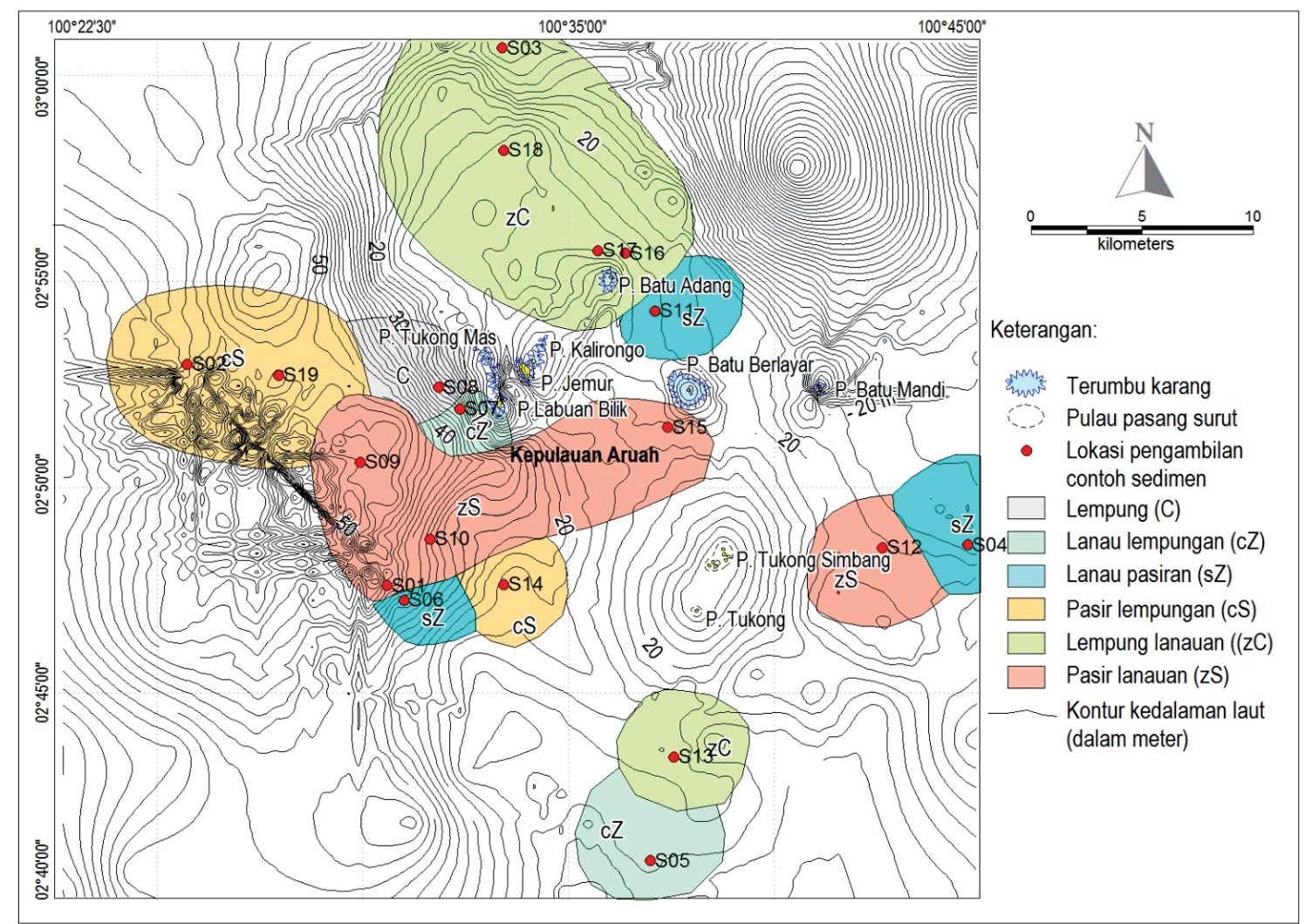

Gambar. 12. Peta penyebaran sedimen permukaan dasar laut dan

Kontur kedalaman dasar laut di perairan Kepulauan Aruah, Provinsi Riau

\section{KESIMPULAN}

Kandungan mineral pada sedimen pasir ditemukan pada contoh sedimen pantai di Pulau Jemur, Pulau Sarong Alang dan Pulau Labuan Bilik, dengan kandungan mineral kuarsa antara $70-80 \%$, kasiterit $1 \%$, hematit 2 - $3 \%$, magnetit, Biotet $1-3 \%$, dolomit $15-2 \%$, yang selanjutnya prospek terdapat pada kedalaman antara 5 - 80 meter, dan terdalam terdapat di bagian utara Pulau Batu Mandi ke arah Selat Malaka. Sedangkan sedimen pasir lempungan dan pasir lanauan yang mengandung mineral letakan ekonomis terdapat pada kedalaman 20 - 50 meter, sehingga kemungkinan sangat mudah untuk ditambang dengan teknologi sekarang ini.
Butiran mineral umumnya masih menunjukkan sudut membentuk butiran menyudut tanggung (sub-angular), Hal ini menunjukkan bahwa kandungan mineral pada sedimen di dasar laut hampir sama dengan kandungan mineral pada sedimen pantai, yang merupakan sumber dari mineral di lepas pantai.

\section{UCAPAN TERIMAKASIH.}

Penulis mengucapkan banyak terimakasih kepada rekan-rekan satu tim di lapangan, dan kepada Pemda Provinsi Riau atas kerja samanya sampai selesainya tulisan ini.

\section{DAFTAR PUSTAKA}

Bachelor, B.C., 1983, Sundaland Tin Placer and Late Caenozoic Coastal and Offshore Stratigraphy in Western Malaysia and Indonesia. Unpubl.

Cameron, N.R, Kastawa. W. \& Thompson, S.J., 1982. Peta Geologi Lembar Dumai, Sumatera, sekala 1:250.000. Puslitbang Geologi.

Folk, RL., 1980, Petrology of Sedimentary Rocks, Hamphill Publishing Company Austin, Taxa Gretchen Luepke, 1984, Stability of Heavy Minerals in Sediment. U.S. Geologocal Survey Menlo, California. 


\section{MAKALAH ILMIAH}

Herbert S. Zim, 1978, Rocks and Minerals, (Field Guide and Introduction to the Geology and Chemistry, Western Publishing Company. Inc.

Ringis, J., 1993. Deposit Models for Detrital Heavy Minerals on East Asian Shelf Areas and the Use of High Resolution Seismic Profiling Techniques in Their Exploration, CCOP Publication.

Rittenhouse, G., 1943. Transportation and Deposition of Heavy Minerals; Geology Society American Bulletin, USA.

Rubey, W.W., 1933. The Size Distribution of Heavy Minerals Within A Water-laid Sandstone; Journal Sediment Petrology

Usman, E. dan Subandrio, A.S., 2009. Eksplorasi Potensi Konsentrat Timah Berdasarkan Data Seismik Refleksi: Studi Kasus Perairan Bangka Utara. Prosiding Kolokium Puslitbang Tekmira 2009, Bandung. 